New Zealand journal of industrial relations, $1988,13,79-86$

\title{
An offer they can't refuse: the imposition of final offer arbitration in the New Zealand state sector
}

\author{
Karen Roper*
}

\section{Introduction}

On 10 March 1988, three months to the day after the introduction of the State Sector Bill, the Government announced a number of changes to the Bill, amongst which was the following:

A provision will be included in the law that will allow the negotiating parties to a particular document to agree to a compulsory arbitration arrangement in return for a "no-strike" commitment from the union. The type of arbitration available will be "final offer" arbitration where the Arbitration Commission must choose between the whole position put forward by one party or the other and cannot go "down the middle" (Government Press Statement, March 10,1988).

Final offer arbitration (FOA) is a new concept for the New Zealand industrial relations system. It was not canvassed in the Buff Paper. Its potential application in this country has certainly not been the subject of debate amongst industrial relations practitioners. This is typical of the way in which this Bill was processed from its introduction. It bodes ill for the future of such an alien element in state sector bargaining.

\section{What is final offer arbitration ?}

It is important to note that there are many different forms of FOA. The Government's initial statement did not make this clear, and indeed gave no indication that it had taken into account the complexities and the options involved in the many varieties of FOA.

The Government's statement suggested a preference for the most extreme version of FOA. This involves an arbitrator being presented with the union's final claim and the employer's final offer after the parties have failed to reach agreement in the course of collective bargaining. The arbitrator must choose one or other of the two positions presented, in its entirety, and may not select some items from each offer. Nor may he or she reach a decision which involves compromise between the final positions of the two parties. In this version, once the final offers have been submitted to the arbitrator, the parties cannot 
change them. However, it is possible for the parties to reach agreement between themselves before the arbitrator has made a ruling, thereby ending the arbitration process. This form is often called restrictive final offer arbitration because the rules are extremely rigid.

Now that the State Sector Act is available, we can see that the type of FOA introduced tends towards this restrictive model. However there have been some modifications to this.

In countries where FOA has been used, a range of more flexible versions of FOA have evolved, as a result of dissatisfaction with the practical results of restrictive FOA. Some of these variations are listed below, together with comments on whether each specified variation is to apply to the new state sector industrial relations system.

(1) With "issue-by-issue" FOA, the arbitrator is able to select a number of items from the union's final claim, and the rest from the employer's final offer. This introduces an element of compromise which brings this type of FOA closest to the conventional compulsory arbitration system with which we are familiar in New Zealand. Under the State Sector Act, however, the arbitrators may not select some items from each case. They must choose between the two final positions.

(2) Dual offer FOA enables each party to provide the arbitrator with two different final positions, giving four options instead of two.This will not apply in New Zealand.

(3) In some jurisdictions, a tripartite panel makes the decision, instead of a single arbitrator. Under the State Sector Act, the arbitration will be carried out by the Arbitration Commission established under the Labour Relations Act, comprising three Commissioners appointed by the Governor General on the advice of the Minister of Labour, plus two members drawn from a panel of employer and union nominees (one representing each side).

(4) It is possible to allow mediation to occur during the course of arbitration, conducted either by the arbitrator(s) or by another neutral party. In the State Sector Act there is no provision for mediation once FOA has started. However, any case referred for FOA will first have passed through the procedures for dealing with unsettled disputes set out in section 147 of the Labour Relations Act (i.e. an Arbitration Commissioner will have explored with the parties the following options: voluntary arbitration; reference of the dispute to the chief mediator to arrange for informal negotiations to try to resolve the dispute; reference back to the mediator for further negotiations in a conciliation council; and, involvement of the central union and employer organisations to attempt to break the
deadlock.

(5) Some FOA arrangements provide for an independent assessment of the relative merits of the two cases (sometimes called 'fact finding'), giving the arbitrator a third option from which to choose. There is no provision for independent assessment of the cases in the New Zealand experiment.

(6) Some arbitrators are permitted to refer FOA cases back to the parties for further negotiations at any point during the arbitration process. While there is no explicit provision for this in the State Sector Act, there is nothing to prevent the parties reaching agreement on identical final offers in terms of the procedure discussed in (8) below.

(7) In some jurisdictions the arbitrator(s) may reject the final offers presented, and request the parties to submit new final offers for consideration. This will not apply in New
Zealand. 
(8) In some versions of FOA, the parties may revise their final offers before the arbitrator's decision is announced. This has been introduced into the State Sector Act. The Commission must give each of the parties the opportunity to restate their final offer after the arbitration hearing and before the decision is made.

If "restate" means "revise" (as presumably it does or there is no point to the provision) then this contains some potential for flexibility. The important variables will be:

(a) whether the Arbitration Commission is prepared to give an indication of its thinking on the case before sending the parties away to "restate" their final offers; and

(b) whether the Government will allow the SSC, as employer party, the autonomy to revise its final offer.

If (a) applies, then presumably the Arbitration Commission could communicate to the parties what it considers to be the strongest points from each case before sending them away to "restate" their final offers. This would allow the parties to attempt to present the most attractive final offer to the Commission by moving closer on some items to the other party's position if it is clear that the Commission prefers that position. There is even the prospect of both parties agreeing to present identical final offers at this point in the process.

If, however, the Commission were to indicate a preference for the entire case of one side, or the great bulk of it, over that of the other party, there would be no incentive for that side to modify its case.

The problem with post-hearing revisions of the final offers is that the Commission will actually be determining a different case from that for which it has heard the arguments. It would be possible for one or both "restated" final offers to be radically different from the original final offers.

(Note the obvious semantic difficulties arising from the notion of parties presenting "final" offers which can later be revised. The concept of "final final" offers is created).

(9) Under FOA there may be criteria established on which the arbitrator(s) must base their decisions, or arbitrators may be left to exercise their own judgement as to which is the more reasonable or workable final offer. The criteria which will apply to FOA in the state sector in New Zealand are those for voluntary arbitration under S148 of the Labour Relations Act.

(10) Time limits may be imposed on both the collective bargaining and arbitration processes. Under the State Sector Act the Arbitration Commission will impose time limits on the restatement of final offers. The timetable will therefore depend largely on the workload of the Commission.

(11) Each party may be required to bear their own costs under FOA, although in the pblic sector in other countries these are sometimes carried by the employer as the agent of the state.In New Zealand the parties will bear their own costs - a factor which may be a deterrent to small unions whose resources are vastly less than those of the state employer.

There are a number of other detailed points which will apply to state sector FOA. The union will decide whether it wishes to have the option of FOA. The SSC and the Arbitration Commission must accept such a clause in an award or agreement if the union 
wants it. However, once the union has opted for FOA it must retain that provision for two negotiating cycles. Employers will forfeit their right to lock out when unions give up the right to strike in exchange for FOA.

\section{Experience with final offer arbitration}

Final offer arbitration has been available in a number of states in the USA since 1971. By 1986 twelve states operated it in one form or another (Bassett p 114). It applies only to public sector employees, (with the recent exception of professional baseball players!) who had no right to strike even before FOA was introduced.

Under the name "pendulum arbitration'", FOA has recently been introduced as a component of "strike free" packages in certain British companies. The brainchild of Roy Sanderson of the Electrical, Electronic, Telecommunication and Plumbing Union (EETPU), these deals have been struck with companies such as Nissan and Toshiba. The whole package includes recognition of a single union for the plant, provision of full company information to the union, industrial democracy in the workplace, flexible work arrangements and comprehensive training programmes, as well as pendulum arbitration as a substitute for strike action. These developments are, of course, highly controversial within the union movement in the U.K., and even where the deals have been made, unions argue that they have not given up their right to strike, but have merely agreed to waive it in situations where the employer delivers the rest of the package. Indeed, in the one case where pendulum arbitration had actually been applied in the U.K. before 1986 ( at Bowman Webber in Essex where the union is EETPU), a strike took place before the case was referred for arbitration (Bassett pp143-6).

It is important to note that neither the British nor the American contexts is directly comparable to that of the state sector in New Zealand in 1988, although some provisions in the recent Nissan agreement here are similar to agreements in the U.K. Moreover, overseas experience is limited and recent. Including FOA in the State Sector Act must therefore be regarded as an experiment. The wisdom of introducing such a novel process into state sector industrial relations at a very late stage in the production of the State Sector Bill must be questioned, especially as there had been no prior discussion of the issue with state unions ( although, this was of course also characteristic of the Bill as a whole). Because the amendment was introduced after the select committee hearings were completed, there was no chance even of submissions on the subject. FOA is not only untried in New Zealand; it has not even been discussed.

\section{The theoretical justification for final offer arbitration}

The purpose of FOA is that it not be used. If a case is referred for FOA, the system can be said to have failed. The whole point of introducing FOA is to eliminate strikes and to encourage settlements reached by collective bargaining because of the strike-like risks of FOA. The theory favours the restrictive type of FOA on the grounds that the parties are forced to be reasonable on every item of their claims and offers because they know that the
result is all or nothing for them.

The argument is that FOA is preferable to conventional arbitration because it forces the parties to be realistic. They are said to strive to agree because of the danger that an arbitrator will choose the other side's final offer. The theory is that conventional arbitration encourages the parties to adopt extreme final offers because of the belief that the arbitrator will strike a position which is a compromise. It is also said that 
conventional arbitration has a "narcotic effect" on some unions, which become dependent on it, and a "chilling effect" on collective bargaining because there is little incentive to settle between the parties.

The value judgements behind these theories are that settlements reached by collective bargaining are healthier for the industrial relations system than arbitrated decisions; and that unions which tend to opt for arbitration on a regular basis are somehow inadequate.

Consideration needs to be given to whether the theory works in practice in jurisdictions where FOA applies, and to whether the theory is valid for New Zealand.

\section{Does the theory work in practice ?}

Much of the readily-available literature derives from the 1970 s when there had been very little experience anywhere with the operation of FOA. Some empirical research has been conducted, however, and other commentators have analysed the implicit merits of the theory in the light of experience with conventional arbitration and other aspects of industrial relations practice.

That final offer arbitration is rarely found in its original restrictive form is an indication in itself that the theory does not stand the test of the complex environment of industrial relations. Arbitrators are amongst the strongest critics of the system. While it would be easy to dismiss this as a result of their vested interest in arbitration systems which are designed to be used, their practical experience cannot be dismissed so lightly.

At the time FOA was first proposed as a component in strike-free deals, the British Advisory Conciliation and Arbitration Service (ACAS) commented that pendulum arbitration "may not necessarily stand the test of fairness or improve relations in the longer term" (ACAS Annual Report, 1984, quoted in Bassett, 1987, p.115). Sir John Wood, Chairman of the Central Arbitration Committee comments: "IIt is difficult to determine what is the last offer; it is artificial to hold the parties to their last offer, for if final agreement is preferable to an award, so a movement closer together, even at the last minute, has to be welcome. Few cases involve only one simple issue. Once there is complexity or multiplicity then difficulties arise. The solutions, such as splitting the issues, strike at the fundamental purpose of the reform." ( quoted in Bassett p. 115-6)

The variations which have evolved in the USA have acknowledged the reality that the damage to the industrial relations climate resulting from victory for an unworkable or unacceptable final offer far outweighs the theoretical benefit of encouraging the parties to settle on their own.

Because of the all-or-nothing result, the outcomes of FOA depend more than in conventional arbitration on the arbitrator's perception of what is reasonable, and on the capacity of the parties to foresee what this perception will be.

The paradox of FOA is that although its purpose is to encourage the predominance of bargaining to resolve disputes, it in fact decisively shapes and changes the entire bargaining process. It is not something simply tacked on at the end. Research by Farber at the Massachusetts Institute of Technology suggests that " the risk-averse party submits a more reasonable offer so that it has a higher probability of being chosen by the arbitrator..." But the corollary is that "'"negotiated settlements under FOA are skewed against the more risk-averse party" (1980, p.683). They are likely to concede more for fear of arbitration. 
Farber also concludes that the more the parties differ in their assessment of the arbitrator's likely decision, the wider apart the final offers tend to be. This means that where such negotiations fail, the arbitrator's award will be more extreme. He says, "This trade-off between the incentive for negotiations and the quality of arbitrated awards needs to be addressed explicitly by researchers and policy makers in this area."(1980, p.699)

This is a fundamental flaw in FOA. The quality of the award is deemed to be far less important than the pressure to reach a negotiated settlement. In fact the quality of the settlement is of paramount importance, both to the parties in the particular dispute, and to the industrial relations system as a whole. If the system produces awards which are seen to be unjust or extreme or unworkable, then the parties are likely to lose faith in it and to behave in ways which undermine it further.

Farber also argues;

that outside economic and political factors can affect the outcomes of collective bargaining under FOA only to the extent that these factors affect the behaviour of the arbitrator. This suggests that empirical work on FOA is needed which focuses on understanding the behaviour of the arbitrator and on understanding how the parties form their expectations about this behaviour $(1980$, p.700)

After analysing the case for and against FOA, Miller concludes that "if the circumstances of a dispute are such that an arbitration award is necessary, I believe that conventional arbitration would result in more workable results. In the hands of a competent and experienced arbitrator, conventional arbitration permits the criteria of fairness, comparability and ability to pay to be more effectively translated into award terms." (1983, p.15)

Grodin reached a similar conclusion about the intrinsic merits of conventional and final offer arbitration:

\footnotetext{
The success of any arbitration scheme depends ultimately on its acceptance by the employees and the public. To the extent that employees view it as rational and fair, they are more likely to abide by its results. Compulsory arbitration already faces sufficient difficulty in gaining acceptance without burdening it further by the undiscriminating imposition of a procedure which has little in the way of a track record and quite a lot in the way of potential problems. 1972, p.265-6)
}

\section{Is the theory valid for New Zealand}

One of the strengths of conventional arbitration in New Zealand is that some state unions (such as NZEI) have learned that this is the only way that they can achieve a settlement which their members will accept as fair. True collective bargaining cannot take place for such groups, because of cabinet intervention in influencing the level and nature of the employer's offer. For such groups, FOA will be seen as a vastly inferior mechanism than conventional arbitration because in FOA fairness is not a consideration in selecting one of the final offers.

Given the balance of power between the employer and unions in state sector industrial relations, unions are likely to be the more risk-averse party in New Zealand. If Farber's analysis is correct, the result will be to achieve lower settlements for unions which have in the past resorted to compulsory arbitration No doubt this is one of the Government's aims in introducing this system. 
Farber's argument that under FOA political and economic factors affect the outcomes of collective bargaining only through the arbitrator stimulates thought about how governments in New Zealand might react if they consider FOA is working against their interests.

This is an important point for considering the application of FOA to the state sector in New Zealand. There is a long tradition of government interference with arbitration institutions (their composition, jurisdiction, etc) when those institutions are perceived by governments to be acting against the interests of the state. When the state is also the employer, this threat hangs over the heads of both the arbitrator and the unions. If decisions go too often against the state employer, the government will be tempted to alter the rules in its favour. If decisions go too often the other way, unions will rapidly become alienated from the system. This is already a problem under conventional arbitration. It is potentially much worse under FOA because if the Government loses a case, the impact is much greater than if a less extreme decision were reached under conventional arbitration. The temptation for government interference is much greater. It is ironic that although unions have to commit themselves to FOA for two award rounds, the Government has given no assurance that it will respect the integrity of the arbitral process should decisions consistently go against it.

An irony is that FOA may mean the failure of the state sector industrial relations system to cope with market factors in setting wages and conditions. An arbitrated award based on one of two more or less extreme positions is unlikely to address complexities of recruitment and retention problems. It is possible to envisage situations in which the Commission selects the lower offer, thereby creating or accentuating such problems, and rendering the system unworkable.

There is another potential problem with the application of FOA to state sector bargaining. The Arbitration Commission must apply set criteria when considering cases before it under the Labour Relations Act. This creates the possibility that the Commission may be presented with final offers which are not based upon the criteria which bind the Commission. On the face of it the Commission will be unable to choose a final offer which is incompatible with the criteria it is bound by. It may be intended that the final offers must be compatible with those criteria. If so, this will be another example of FOA shaping the course of collective bargaining. This problem does not arise under conventional arbitration because the Commission is not restricted to the parties' final offers and can reach a decision based upon its statutory criteria.

We will have to wait and see whether FOA is used; whether settlements made under it tend merely to follow the trend for the bargaining round; or whether radical departures from the uniform pattern of settlements emerge from FOA. There is no evidence that any thought has been given to the possible effects on collective bargaining generally of the anomoly that FOA applies only to the state sector.

FOA represents a gamble for state unions, especially in the early years until experience gives a basis for estimating likely decisions on particular cases. Because of this uncertainty and the risks of results which weigh heavily against the union involved, it seems likely that many will opt for publicity and political campaigns or direct action to force the employer party to compromise or agree to voluntary conventional arbitration. 


\section{Conclusion}

There are clearly a large number of pitfalls inherent in the proposal to introduce FOA into the state sector in New Zealand. Neither the Government nor the unions have had sufficient time to consider the complex issues involved. To impose such a radical departure from existing practice at such a late point in the legislative process is potentially destabilising. It is also foolhardy.

\section{References}

Basset P (1987) Strike free:the new industrial relations London, Papermac

Farber H S (1980) An analysis of final offer arbitration Journal of conflict resolution 24 (4): 683-705.

Feuille P (1975) Final offer arbitration and the chilling effect Industrial relations 14 (3): 302-10.

Feuille P and Long G (1974) The public administrator and final offer arbitration Public administration review Nov-Dec : 575-83.

Feigenbaum C (1975) Final offer arbitration: better theory than practice Industrial relations $14(3): 311-17$.

Geare A J (1978) Final offer arbitration: a critical examination of the theory The journal of industrial relations $20(4)$ ): 373-85.

Grodin J R (1972) Either-or arbitration for public employee disputes Industrial relations 11 (2): 260-66.

Long G and Feuilie P Final-offer arbitration: 'sudden death' in Eugene Industrial and labour relations review volume and year not given 186-203.

Millar R L Compulsory arbitration: its uses and abuses (1983) Industrial Relations Centre, Victoria University of Wellington

Wheeler H N (1977) Closed offer: alternative to final offer selection Industrial relations 16 (3): 298-305. 